Author affiliations appear at the end of this article.

Published online ahead of print at www.jco.org on October 3, 2016

Supported by Amgen. A.v.S. and F.L. received funding from the European Union's Seventh Framework Program for Research, Technological Development and Demonstration under Grant

Agreement No. 278514-IntReALL. Amgen also funded the work of Miranda Tradewell, PhD, and Ali Hassan, PhD (Complete Healthcare Communications, LLC, Chadds Ford, PA), who developed an initial draft of the methods and results and who assisted with formatting.

A.v.S., F.L., and G.Z. contributed equally to this work

Presented in abstract form at the 49th Annual Meeting of the American Society of Clinical Oncology, Chicago, IL, May

31-June 3, 2013; the 56th Annual Meeting of the American Society of Hematology, San Francisco, CA, December 6-9, 2014; the 46th Congress of the International Society of Paediatric Oncology, Toronto, Canada, October 22-25, 2014; and the American Society for Blood and Marrow Transplantation, San Diego, CA, February 11-14, 2015.

Authors' disclosures of potential conflicts of interest are found in the article online at www.jco.org. Author contributions are found at the end of this article.

Clinical trial information: NCT01471782.

Corresponding author: Arend von Stackelberg, MD, Charité Campus Virchow-Klinikum, Augustenburger Platz 1 13353 Berlin, Germany; e-mail: arend. stackelberg@charite.de.

(c) 2016 by American Society of Clinical Oncology

0732-183X/16/3499-1/\$20.00

DOI: 10.1200/JCO.2016.67.3301

\title{
Phase I/Phase II Study of Blinatumomab in Pediatric Patients With Relapsed/Refractory Acute Lymphoblastic Leukemia
}

Arend von Stackelberg, Franco Locatelli, Gerhard Zugmaier, Rupert Handgretinger, Tanya M. Trippett, Carmelo Rizzari, Peter Bader, Maureen M. O’Brien, Benoît Brethon, Deepa Bhojwani, Paul Gerhardt Schlegel, Arndt Borkhardt, Susan R. Rheingold, Todd Michael Cooper, Christian M. Zwaan, Phillip Barnette, Chiara Messina, Gérard Michel, Steven G. DuBois, Kuolung Hu, Min Zhu, James A. Whitlock, and Lia Gore

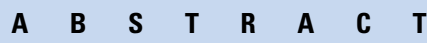

\section{Purpose}

Blinatumomab is a bispecific T-cell engager antibody construct targeting CD19 on B-cell lymphoblasts. We evaluated the safety, pharmacokinetics, recommended dosage, and potential for efficacy of blinatumomab in children with relapsed/refractory B-cell precursor acute lymphoblastic leukemia (BCP-ALL).

\section{Methods}

This open-label study enrolled children $<18$ years old with relapsed/refractory BCP-ALL in a phase I dosage-escalation part and a phase II part, using 6-week treatment cycles. Primary end points were maximum-tolerated dosage (phase I) and complete remission rate within the first two cycles (phase II).

\section{Results}

We treated 49 patients in phase I and 44 patients in phase II. Four patients had dose-limiting toxicities in cycle 1 (phase I). Three experienced grade 4 cytokine-release syndrome (one attributed to grade 5 cardiac failure); one had fatal respiratory failure. The maximum-tolerated dosage was $15 \mu \mathrm{g} / \mathrm{m}^{2} / \mathrm{d}$. Blinatumomab pharmacokinetics was linear across dosage levels and consistent among age groups. On the basis of the phase I data, the recommended blinatumomab dosage for children with relapsed/refractory ALL was $5 \mu \mathrm{g} / \mathrm{m}^{2} / \mathrm{d}$ for the first 7 days, followed by $15 \mu \mathrm{g} / \mathrm{m}^{2} / \mathrm{d}$ thereafter. Among the 70 patients who received the recommended dosage, 27 (39\%; 95\% Cl, 27\% to $51 \%$ ) achieved complete remission within the first two cycles, 14 (52\%) of whom achieved complete minimal residual disease response. The most frequent grade $\geq 3$ adverse events were anemia $(36 \%)$, thrombocytopenia (21\%), and hypokalemia $(17 \%)$. Three patients $(4 \%)$ and one patient $(1 \%)$ had cytokine-release syndrome of grade 3 and 4, respectively. Two patients $(3 \%)$ interrupted treatment after grade 2 seizures.

\section{Conclusion}

This trial, which to the best of our knowledge was the first such trial in pediatrics, demonstrated antileukemic activity of single-agent blinatumomab with complete minimal residual disease response in children with relapsed/refractory BCP-ALL. Blinatumomab may represent an important new treatment option in this setting, requiring further investigation in curative indications.

\section{J Clin Oncol 34. (C) 2016 by American Society of Clinical Oncology}

\section{INTRODUCTION}

Acute lymphoblastic leukemia (ALL) is the most common malignant disease in children, with an annual incidence of approximately three cases per 100,000 persons. ${ }^{1}$ When treated with contemporary combination chemotherapy, approximately $15 \%$ of patients relapse and $10 \%$ die. ${ }^{2,3}$ Patients who relapse have a cure rate ranging from $10 \%$ to $70 \%$, mainly depending on site of and time to relapse. ${ }^{4,5}$ Children with second or greater relapse or refractory disease have a dismal prognosis even when treated with intensive combination chemotherapy and allogeneic hematopoietic stem-cell transplantation (alloHSCT). ${ }^{6,7}$ Targeted treatments are needed to overcome disease resistance and to replace nonspecific toxic chemotherapy, even in children with chemosensitive ALL. Immunotherapy constitutes an important new antileukemic treatment strategy.

CD19 is expressed on B-lineage cells ${ }^{8,9}$ and is a therapeutic target for B-cell precursor ALL 
(BCP-ALL). ${ }^{10}$ Blinatumomab is a bispecific T-cell engager (BiTE) antibody construct that directs CD3-positive effector memory $\mathrm{T}$ cells to CD19-positive target cells, triggering cell death. ${ }^{11,12}$ In a large phase II study in adults with relapsed/refractory BCP-ALL, the response rate after single-agent blinatumomab treatment was $43 \% .{ }^{13}$ We report the results of an international phase I/II study of immunotherapy blinatumomab in children and adolescents with BCP-ALL that was refractory, in second overt relapse, and/or in relapse after alloHSCT.

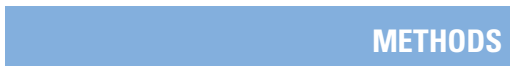

\section{Patients}

We conducted an open-label, single-arm phase I/II study at 26 European and US centers. Eligible patients were $<18$ years of age $(2$ to 17 years of age in phase I dosage escalation) and had BCP-ALL with $>25 \%$ bone marrow blasts. The disease was primary refractory, in first relapse after full salvage induction regimen, in second or later relapse, or in any

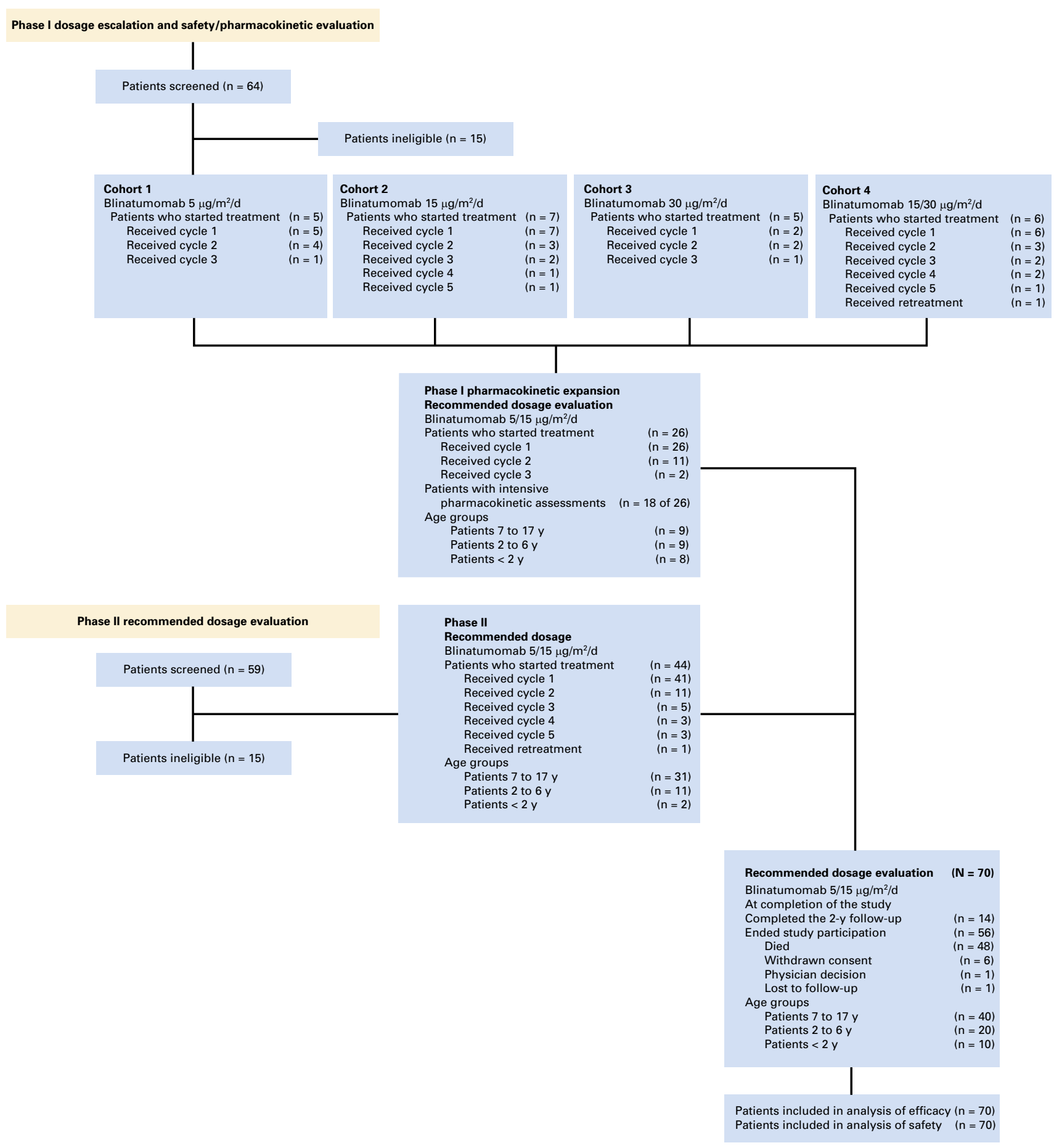

Fig 1. Study profile 
relapse after alloHSCT. Patients had Karnofsky or Lansky (age $<16$ years) performance status of $\geq 50 \%$. Patients with Philadelphia chromosomepositive ALL were eligible; those with active acute or extensive chronic graft-versus-host disease after HSCT, or active CNS or testicular involvement, were excluded. Further eligibility criteria are available in the study protocol (Data Supplement). Each center's institutional review board or an independent ethics committee approved the study protocol. The patients' legal representatives gave written informed consent.

\section{Study Design and Assessments}

The study included a dosage-finding phase I part and a phase II part evaluating safety and efficacy at the recommended dosage proposed by an independent Data Safety Monitoring Board (DSMB) on the basis of the dosage-finding part. In phase I, we tested blinatumomab dosages of 5, 15, and $30 \mu \mathrm{g} / \mathrm{m}^{2} / \mathrm{d}$ and a stepwise dosage of $15 / 30 \mu \mathrm{g} / \mathrm{m}^{2} / \mathrm{d}\left(15 \mu \mathrm{g} / \mathrm{m}^{2} / \mathrm{d}\right.$ for the first 7 days and $30 \mu \mathrm{g} / \mathrm{m}^{2} / \mathrm{d}$ thereafter). After determining the recommended dosage (stepwise $5 / 15 \mu \mathrm{g} / \mathrm{m}^{2} / \mathrm{d}$ ), we treated additional patients to further assess pharmacokinetics and safety across three age groups ( 7 to 17 years; 2 to 6 years; $<2$ years) before beginning phase II (Appendix Fig A1, online only).

Patients received blinatumomab as a 4-week continuous intravenous infusion, followed by a 2 -week treatment-free interval. For stepwise dosing $\left(5 / 15\right.$ or $\left.15 / 30 \mu \mathrm{g} / \mathrm{m}^{2} / \mathrm{d}\right)$, the lower dose was administered for the first week of the first cycle followed by the higher dose for the remaining 3 weeks and subsequent cycles. Infusion was administered in the hospital during week 1 of cycle 1 and during the first 2 days of cycle 2, and in an outpatient setting thereafter. Patients achieving complete remission (CR) within the first two cycles could receive up to three additional cycles or be withdrawn from treatment to receive consolidation chemotherapy or HSCT per the investigator's choice. To prevent cytokine-release syndrome (CRS), dexamethasone or hydroxyurea for 4 days was recommended during the first treatment week and was required if baseline bone marrow blasts were $>50 \%$. Patients received prophylactic dexamethasone $10 \mathrm{mg} / \mathrm{m}^{2} 6$ to 12 hours before and $5 \mathrm{mg} / \mathrm{m}^{2}$ within 30 minutes of each infusion start. CNS prophylaxis according to institutional/national standards was administered at age-adjusted doses before treatment, at day 15 of cycle 1, and at the day 29 bone marrow assessment. Neurologic events were treated with dexamethasone at 0.2 to $0.4 \mathrm{mg} / \mathrm{kg} / \mathrm{d}$ (maximum, $24 \mathrm{mg} / \mathrm{d}$ ) for up to 3 days.

Patients discontinued treatment permanently if they experienced adverse events (AEs) meeting the criteria for dose-limiting toxicities (DLT; Data Supplement), irrespective of their timing; a neurologic event requiring $>1$ week to resolve to grade $\leq 1$; disease progression or hematologic/extramedullary relapse; or treatment interruption/delay of $>2$ weeks or more than two discontinuations for AEs during one cycle. For other blinatumomab-related AEs not meeting DLT criteria but requiring infusion interruption, treatment could be restarted one dosage level lower after resolution to grade $\leq 1$.

Bone marrow aspiration (and/or biopsy) for response assessment was performed during screening, at day 15 of cycle 1 , and at the end of each 28-day cycle. Hematologic responses were assessed locally and were confirmed by central reference laboratory. CR was defined as no evidence of circulating blasts or extramedullary disease and $<5 \%$ blasts in bone marrow (M1). CR was subclassified on the basis of recovery of peripheral blood counts. Minimal residual disease (MRD) response was assessed by central laboratories; data presented are based on flow cytometry. MRD response was defined as $<10^{-4}$ detectable blasts; complete MRD response was defined as no detectable blasts. All AEs occurring from treatment start until 30 days after the last infusion were recorded and graded according to National Cancer Institute Common Terminology Criteria for Adverse Events version 4.03. ${ }^{14}$ Anti-blinatumomab antibodies were assessed.

\section{End Points}

The primary phase I end point was the maximum-tolerated dosage (MTD), the maximal dosage at which one or fewer of six patients experienced a DLT. Secondary end points included pharmacokinetics and $\mathrm{AE}$ incidence. The primary phase II end point was the $\mathrm{CR}$ rate within the first two cycles. Secondary end points included AE incidence, proportion of patients undergoing alloHSCT after blinatumomab treatment, relapse-free survival (RFS), and overall survival (OS). MRD response and complete MRD response were exploratory end points in both phases.

\section{Statistical Analysis}

Phase I followed a rolling six design. ${ }^{15}$ The phase II sample size was based on a Simon-like two-stage design. ${ }^{16}$ A minimum of 40 patients (first stage, $\mathrm{n}=21$; second stage, $\mathrm{n}=19$ ) was estimated to be needed to provide $80 \%$ power to test the null hypothesis, with two-sided $\alpha=0.05$, that achievement of CR within the first two cycles was $\leq 10 \%$ versus the alternative hypothesis of $27.5 \%$. The proportion of responders with exact

\begin{tabular}{|c|c|c|c|}
\hline Characteristic & $\begin{array}{l}\text { All Patients in } \\
\text { Phase I } \\
(n=49)\end{array}$ & $\begin{array}{l}\text { All Patients in } \\
\text { Phase II } \\
(n=44)\end{array}$ & $\begin{array}{l}\text { All Patients at } \\
\text { Recommended } \\
\text { Dosage* }(n=70)\end{array}$ \\
\hline \multicolumn{4}{|l|}{ Sex } \\
\hline Male & $28(57)$ & 32 (73) & $47(67)$ \\
\hline Female & $21(43)$ & $12(27)$ & $23(33)$ \\
\hline \multicolumn{4}{|l|}{ Geographic region } \\
\hline European Union & $34(69)$ & 31 (71) & $48(69)$ \\
\hline United States & $15(31)$ & $13(30)$ & $22(31)$ \\
\hline \multicolumn{4}{|l|}{ Age group, years } \\
\hline$<2$ & $8(16)$ & 2 (5) & $10(14)$ \\
\hline $2-6$ & $23(47)$ & $11(25)$ & $20(29)$ \\
\hline $7-17$ & $18(37)$ & $31(71)$ & $40(57)$ \\
\hline $\begin{array}{l}\text { Age, median (range), } \\
\text { years }\end{array}$ & $6(<1-16)$ & $10.5(<1-17)$ & $8(<1-17)$ \\
\hline \multicolumn{4}{|l|}{ Genetic abnormalities } \\
\hline$M L L$ total & $10(20)$ & $2(5)$ & $10(14) \dagger$ \\
\hline MLL-AF4.t(4;11) & $7(14)$ & $2(5)$ & $8(11)$ \\
\hline Other MLL & $3(6)$ & 0 & $2(3)$ \\
\hline$B C R-A B L$ & $2(4)$ & $1(2)$ & 2 (3) \\
\hline Hypodiploidy & $1(2)$ & $3(7)$ & $4(9)$ \\
\hline Constitutional trisomy 21 & $1(2)$ & $1(2)$ & $2(3)$ \\
\hline \multicolumn{4}{|l|}{ Previous alloHSCT } \\
\hline Yes & $30(61)$ & $25(57)$ & $40(57)$ \\
\hline No & $19(39)$ & $19(43)$ & $30(43)$ \\
\hline \multicolumn{4}{|l|}{ Previous relapses } \\
\hline 0 & $2(4)$ & 0 & $2(3)$ \\
\hline 1 & $17(35)$ & $22(50)$ & $31(44)$ \\
\hline 2 & $23(47)$ & $19(43)$ & $29(41)$ \\
\hline$\geq 3$ & $7(14)$ & $3(7)$ & $8(11)$ \\
\hline Refractory disease & $26(53)$ & $26(59)$ & $39(56)$ \\
\hline $\begin{array}{l}\text { Time between last } \\
\text { relapse and first } \\
\text { blinatumomab } \\
\text { infusion, median } \\
\text { (range), months }\end{array}$ & $1.8(0.1-16.1)$ & $1.9(0.2-13.7)$ & $2.9(0.4-49.8)$ \\
\hline $\begin{array}{l}\text { Relapse within } 6 \text { months } \\
\text { after last prior } \\
\text { treatment attempt }\end{array}$ & - & - & $50(71)$ \\
\hline \multicolumn{4}{|l|}{$\begin{array}{l}\text { Bone marrow blast count } \\
\text { per central } \\
\text { laboratory, \% }\end{array}$} \\
\hline$<50$ & $7(14)$ & $12(27)$ & $18(26)$ \\
\hline$\geq 50$ & $42(86)$ & 32 (73) & $52(74)$ \\
\hline
\end{tabular}

NOTE. Data are presented as No. (\%) unless otherwise indicated. Abbreviations: alloHSCT, allogeneic hematopoietic stem-cell transplantation; $B C R-A B L$, breakpoint cluster region-Abelson murine leukemia viral oncogene homolog 1 gene; $M L L$, mixed-lineage leukemia gene.

*All patients treated at the stepwise dosage of $5 / 15 \mu \mathrm{g} / \mathrm{m}^{2} / \mathrm{d}$ in phase I or phase II.

†Eight patients with $M L L$ translocations were $<2$ years old: six had $M L L$ with the fusion partner AF4.t(4;11); two had other MLL abnormalities. 
95\% CIs was calculated. RFS and OS (time from enrollment to first relapse or death, respectively) were estimated using the Kaplan-Meier method. We conducted separate primary analyses for both study phases (Data Supplement). Pooled analysis of data from patients who received the recommended dosage in phases I or II was exploratory. Efficacy/safety analyses were based on the full-analysis set (all patients who received any blinatumomab infusion). Pharmacokinetic parameters were estimated using noncompartmental methods with Phoenix WinNonlin version 6.3 software on Citrix (Pharsight, St. Louis, MO).

\section{RESULTS}

\section{Patient Characteristics}

Between January 30, 2012, and June 3, 2014, we treated 49 patients in phase I and 44 patients in phase II (Fig 1). Patients were considered very high risk on the basis of baseline tumor load, multiple prior relapses, short interval between latest treatment and start of blinatumomab, previous alloHSCT, and/or cytogenetic profile. Most patients were refractory to their last treatment (Table 1). At the date of study completion (May 24, 2016), all patients had completed the 2-year follow-up, had withdrawn from study, or had died.

\section{Phase I Dosage-Finding Part and Pharmacokinetics}

Four DLTs (two fatal) occurred in phase 1 (Data Supplement): one grade 4 CRS deemed to be related to grade 4 GI hemorrhage at $15 \mu \mathrm{g} / \mathrm{m}^{2} / \mathrm{d}$; two grade 4 CRS at $30 \mu \mathrm{g} / \mathrm{m}^{2} / \mathrm{d}$ (one attributed to grade 5 cardiac failure and the other treated successfully with tocilizumab $\left.{ }^{17}\right)$; and one case of grade 5 respiratory failure $\left(15 / 30 \mu \mathrm{g} / \mathrm{m}^{2} / \mathrm{d}\right)$ with cardiac arrest after hypotonia and muscle weakness after 7 days of infusion with blinatumomab at $15 \mu \mathrm{g} / \mathrm{m}^{2} / \mathrm{d}$ (30 $\mathrm{\mu g} / \mathrm{m}^{2} / \mathrm{d}$ was not administered). This patient experienced febrile neutropenia and pneumonia shortly before infusion start. Thus, the MTD was determined to be $15 \mu \mathrm{g} / \mathrm{m}^{2} / \mathrm{d}$. Across dosage cohorts, the incidence of AEs not considered DLTs was also dosage dependent (Data Supplement). Considering the MTD and overall toxicity profile, and to reduce the risk of CRS, the independent DSMB recommended the stepwise dosage of $5 / 15 \mu \mathrm{g} / \mathrm{m}^{2} / \mathrm{d}$ for further evaluation.

Twenty-six patients in three age groups (those $<2$ years old were enrolled last) were then assessed at $5 / 15 \mu \mathrm{g} / \mathrm{m}^{2} / \mathrm{d}$ in the phase I pharmacokinetic expansion. Blinatumomab had approximately linear pharmacokinetics. Steady-state concentration was similar at a given dosage across age groups and was similar to adult reference data (Data Supplement). Although DLTs were not collected formally in the pharmacokinetic expansion, no AEs that

Table 2. Efficacy Outcomes and Ability to Proceed to Transplantation for Patients who Received the Recommended Dosage

\begin{tabular}{|c|c|c|c|c|c|c|c|c|c|}
\hline \multirow[b]{2}{*}{ Efficacy Outcomes and Ability to Proceed to alloHSCT } & \multicolumn{3}{|c|}{$\underline{\text { Patients in Phase II }(n=44)^{*}}$} & \multicolumn{3}{|c|}{$\begin{array}{c}\text { All Patients at Recommended } \\
\text { Dosage } \\
(\mathrm{n}=70)^{*} \\
\end{array}$} & \multicolumn{3}{|c|}{$\begin{array}{l}\text { Patients }<2 \text { Years at } \\
\text { Recommended Dosage } \\
(n=10)^{*}\end{array}$} \\
\hline & No. & $\%$ & $95 \% \mathrm{Cl}$ & No. & $\%$ & $95 \% \mathrm{Cl}$ & No. & $\%$ & $95 \% \mathrm{Cl}$ \\
\hline \multicolumn{10}{|l|}{ Hematologic response } \\
\hline CR within the first two cycles & 14 & 32 & 19 to 48 & 27 & 39 & 27 to 51 & 6 & 60 & 26 to 88 \\
\hline \multicolumn{10}{|l|}{ Nonresponders (did not achieve CR) } \\
\hline Partial remission & 3 & 7 & & 4 & 6 & & 0 & 0 & \\
\hline Blast-free hypoplastic or aplastic bone marrow & 0 & 0 & & 2 & 3 & & 0 & 0 & \\
\hline Progressive disease & 8 & 18 & & 10 & 14 & & 2 & 20 & \\
\hline No response & 14 & 32 & & 21 & 30 & & 2 & 20 & \\
\hline No response assessment $\dagger$ & 5 & 11 & & 6 & 9 & & NA & NA & \\
\hline \multicolumn{10}{|l|}{$\begin{array}{c}\text { CR within the first two cycles by baseline bone } \\
\text { marrow blast count }\end{array}$} \\
\hline$<50 \%$ blasts at baseline & 5 of 12 & 42 & 15 to 72 & 10 of 18 & 56 & 31 to 79 & 2 of 2 & 100 & 16 to 100 \\
\hline$\geq 50 \%$ blasts at baseline & 9 of 32 & 28 & 14 to 47 & 17 of 52 & 33 & 20 to 47 & 4 of 8 & 50 & 16 to 84 \\
\hline Relapse or death after CR $\ddagger$ & 10 of 14 & 71 & & 7 of 27 & 26 & & 4 of 6 & 67 & \\
\hline \multicolumn{10}{|l|}{$\begin{array}{l}\text { MRD response in patients who achieved CR within } \\
\text { the first two cycles }\end{array}$} \\
\hline MRD response & 8 of 14 & 57 & 29 to 82 & 14 of 27 & 52 & 32 to 71 & 3 of 6 & 50 & 12 to 88 \\
\hline Complete MRD response & 8 of 14 & 57 & 29 to 82 & 14 of 27 & 52 & 32 to 71 & 3 of 6 & 50 & \\
\hline No MRD response & 6 of 14 & 43 & & 12 & 44 & & 3 of 6 & 50 & \\
\hline No data available & 0 & 0 & & 1 & 4 & & 0 & 0 & \\
\hline \multicolumn{10}{|l|}{ Ability to proceed to HSCT } \\
\hline Patients who received alloHSCT & 13 & 30 & & 24 & 34 & & 4 & 10 & \\
\hline Patients in blinatumomab-induced CR & 5 & 11 & & 13 & 19 & & 4 & 40 & \\
\hline Patients in CR who received only blinatumomab & 2 & 5 & & 8 & 11 & & 2 & 20 & \\
\hline 100-day mortality rate§ & & NE & NE & & 25 & 7 to 69 & & NE & NE \\
\hline Nonresponders who received subsequent treatments $\|$ & 8 & 18 & & 11 & 16 & & NA & NA & \\
\hline \multicolumn{10}{|c|}{$\begin{array}{l}\text { Abbreviations: alloHSCT, allogeneic hematopoietic stem-cell transplantation; CR, complete remission; HSCT, hematopoietic stem-cell transplantation; MRD, minimal } \\
\text { residual disease; NA, not applicable; NE, not evaluated. } \\
{ }^{*} \text { All patients treated at } 5 / 15 \mu \mathrm{g} / \mathrm{m}^{2} / \mathrm{d} \text { in phase I or II. } \\
\text { †Patients died ( } \mathrm{n}=5 \text { ) or withdrew consent }(\mathrm{n}=1 \text { ) before the first response assessment. } \\
\text { łRelapse during the efficacy follow-up (no chemotherapy or alloHSCT between end of blinatumomab treatment and relapse). } \\
\text { §Calculated from the date of alloHSCT for all patients who received only blinatumomab at the recommended dose. Not calculated for the other two patient groups } \\
\text { because of limited sample size. } \\
\text { "IPatients who were refractory to blinatumomab but who received subsequent treatments and then proceeded to alloHSCT. }\end{array}$} \\
\hline
\end{tabular}


occurred would have met the definition of a DLT. The nature and incidence of AEs were consistent with previous blinatumomab experience (Data Supplement). After review of the toxicity data, the DSMB confirmed $5 / 15 \mu \mathrm{g} / \mathrm{m}^{2} / \mathrm{d}$ as the recommended dosage for phase II.

In phase I, seven of 23 patients $(30 \%)$ in the dosage-escalation part achieved CR within the first two cycles, with all responders achieving a complete MRD response (Data Supplement). Responses were observed at all dosage levels.

\section{Efficacy at the Recommended Dosage}

On the basis of the primary analysis (January 12, 2015), 14 of 44 patients (32\%; 95\% CI, $19 \%$ to $48 \%$ ) in phase II who received the recommended dosage of $5 / 15 \mu \mathrm{g} / \mathrm{m}^{2} / \mathrm{d}$ achieved CR within the first two cycles (Table 2). Overall, 70 patients received this dosage in phase I $(\mathrm{n}=26)$ or phase II $(\mathrm{n}=44)$. Twenty-seven patients $(39 \% ; 95 \%$ CI, $27 \%$ to $51 \%)$ achieved CR within the first two cycles (Table 2), 20 (74\%) within cycle 1 and eight of those (30\%) by day 15 of cycle 1 . At the day 15 assessment, three patients who ultimately responded still had M3 marrow, two had M2 marrow; all other responders had either hypocellular or M1 marrow.

Prespecified analyses showed that CRs had been achieved across subgroups (Fig 2). The CR rate was 56\% among patients with $<50 \%$ bone marrow blasts at baseline versus 33\% among those with $\geq 50 \%$ blasts. Two of three $\mathrm{Ph}$-positive patients and one of four patients with hypodiploidy achieved CR (Data Supplement). One of two patients with constitutional trisomy 21 had partial remission. Among 10 patients $<2$ years of age (eight with $M L L$ translocations), six (60\%) achieved CR (including five with $M L L$ translocations; Data Supplement), with four (40\%) proceeding to alloHSCT in remission. Of the 27 responders treated with blinatumomab $5 / 15 \mu \mathrm{g} / \mathrm{m}^{2} / \mathrm{d}$, four were still in remission at the end of the 2-year follow-up, two had relapsed but were still alive, three had withdrawn consent (one patient in CR and two after relapse), three had died in CR after alloHSCT, and 15 had relapsed and died (four with a CD19-negative clone).

Fourteen of 27 responders (52\%) had a complete MRD response, $13(48 \%)$ by day 15 of cycle 1 . Complete MRD response rates were similar across subgroups, with different peripheral counts at response assessment (Data Supplement). Thirteen of the 27 patients $(48 \%)$ received alloHSCT in blinatumomabinduced remission (seven of whom had received alloHSCT previously).

Forty-three patients did not achieve CR within the first two cycles. At the end of the 2-year follow-up, eight were still alive. Eleven nonresponders received postblinatumomab alloHSCT. Mean cumulative prophylaxis and treatment dexamethasone dose did not differ between responders and nonresponders $\left(72.4 \mathrm{mg} / \mathrm{m}^{2} v 76.3\right.$, respectively).

Median RFS was 4.4 months (95\% CI, 2.3 to 7.6 months) among patients receiving the recommended dosage who achieved CR, with a median follow-up of 23.1 months (Fig 3A). The RFS rate at 6 months was $42 \%$. Median RFS was longer for patients with a complete MRD response (7.3 months; $95 \%$ CI, 2.7 to 16.4 months; $\mathrm{n}=14)$ than for those without (1.9 months; $95 \%$ CI, 0.8 to 6.0 months; $\mathrm{n}=12$; Fig 3B). Median OS for all 70 patients was 7.5 months (95\% CI, 4.0 to 11.8 months) with a median follow-up of 23.8 months (Fig 3C).

\section{AEs at the Recommended Dosage}

Among the 70 patients who received blinatumomab $5 / 15 \mu \mathrm{g} / \mathrm{m}^{2} / \mathrm{d}$, the most common AEs, regardless of causality, were pyrexia ( $80 \%)$, anemia (41\%), nausea (33\%), and headache $(30 \%$;

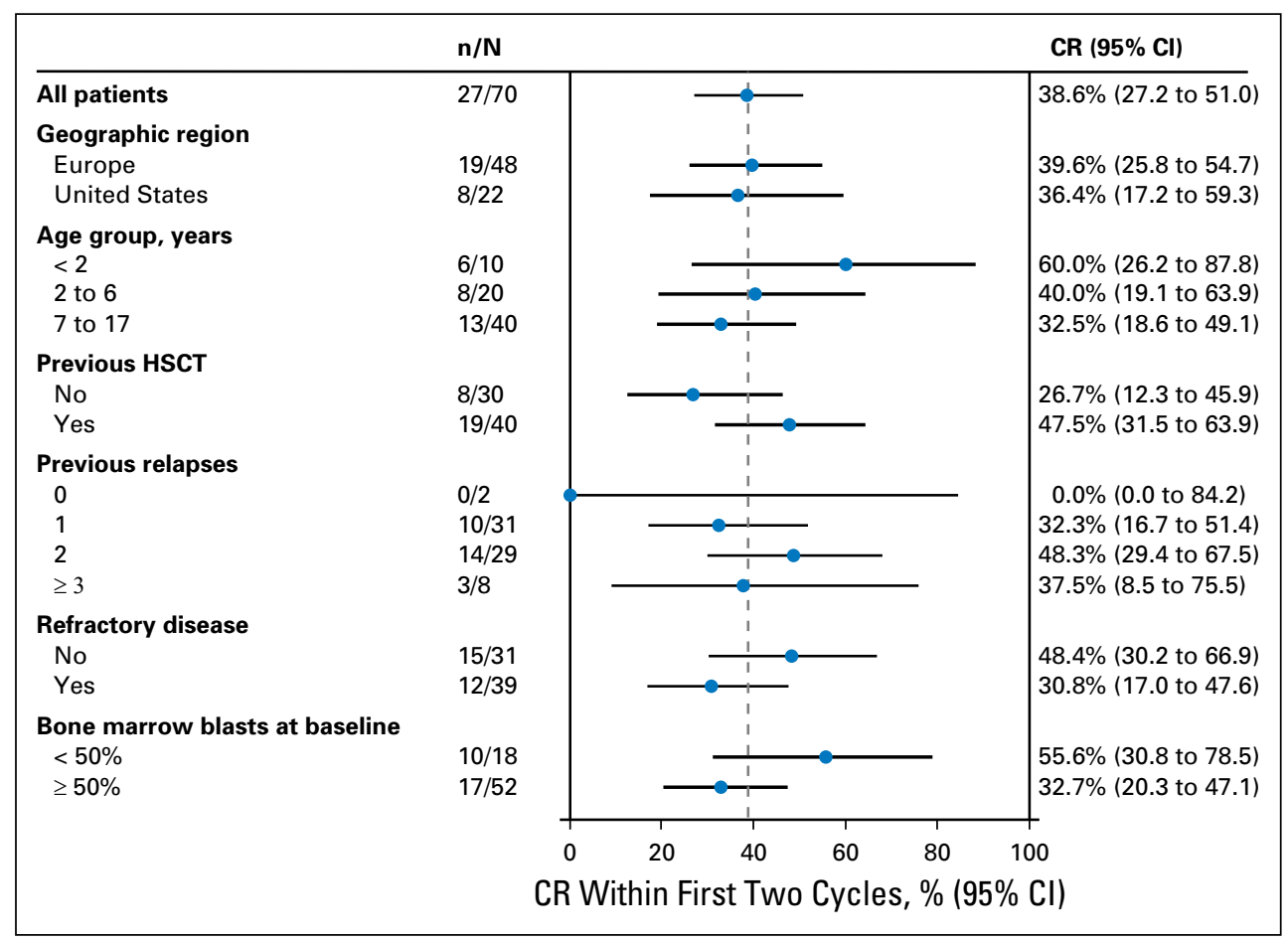

Fig 2. Complete remission (CR) rates within two treatment cycles among patient subgroups (prespecified analysis). The point estimate for $\mathrm{CR}$ for all patients who received the recommended dosage is indicated by a dashed line. HSCT, hematopoietic stem-cell transplantation. 
Data Supplement). Grade 3 and 4 AEs were primarily cytopenias (Table 3). Most AEs occurred in the first few days of cycle 1 (data not shown). Six of 70 patients had fatal AEs; three died after alloHSCT after blinatumomab-induced remission (Table 3). Ten patients (14\%) interrupted treatment and four (6\%) discontinued treatment permanently because of AEs (Data Supplement). Two permanent discontinuations were considered treatment related (grade 3 and 4 CRS). No patient developed anti-blinatumomab antibodies during the study.
Eight $(11 \%)$ of the 70 patients treated with $5 / 15 \mu \mathrm{g} / \mathrm{m}^{2} / \mathrm{d}$ had CRS of any grade (Data Supplement). Three patients had grade 3 and one patient had grade 4 CRS. All four patients interrupted treatment $(\mathrm{n}=2)$ or discontinued treatment permanently $(\mathrm{n}=2$; after 3 days [cycle 1] and 10 days [cycle 2] of infusion, respectively). All four patients achieved CR at response assessment. Peak levels of interleukin-10, interleukin-6, and interferon- $\gamma$ were higher in patients with CRS than in patients without, although sample sizes were small (Data Supplement).

\section{A}

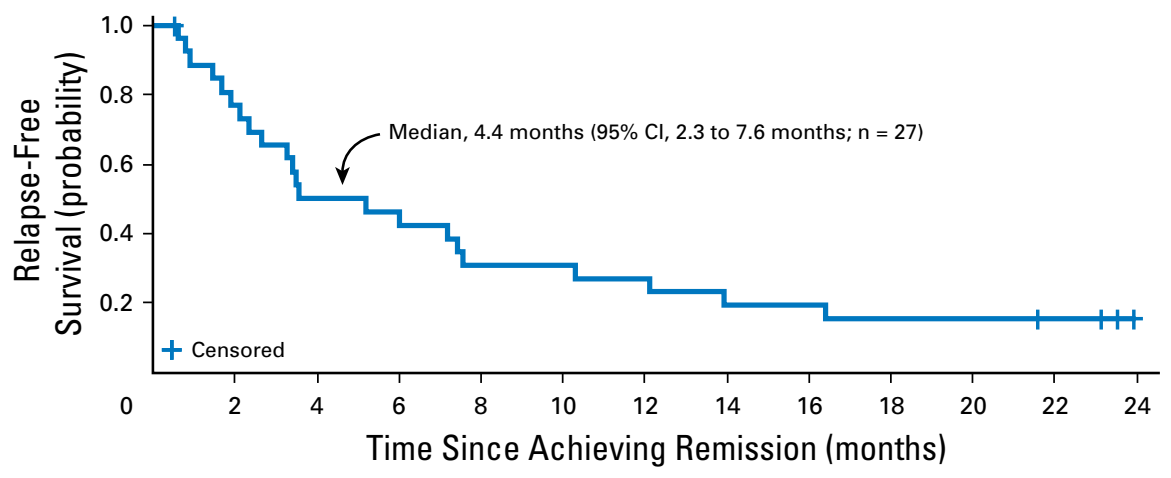

B

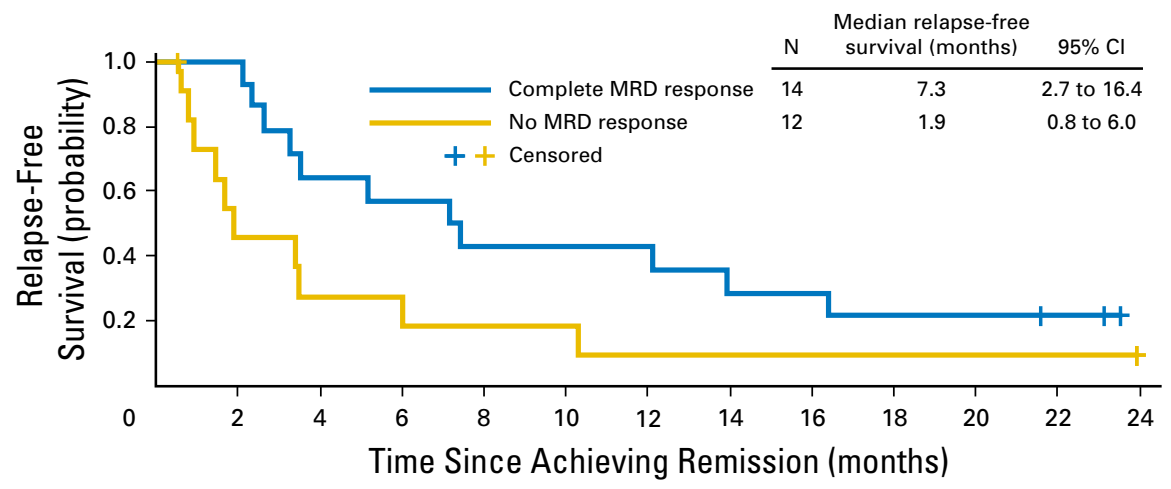

No. at risk:

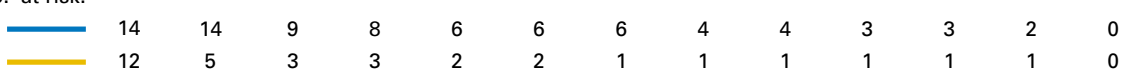

C

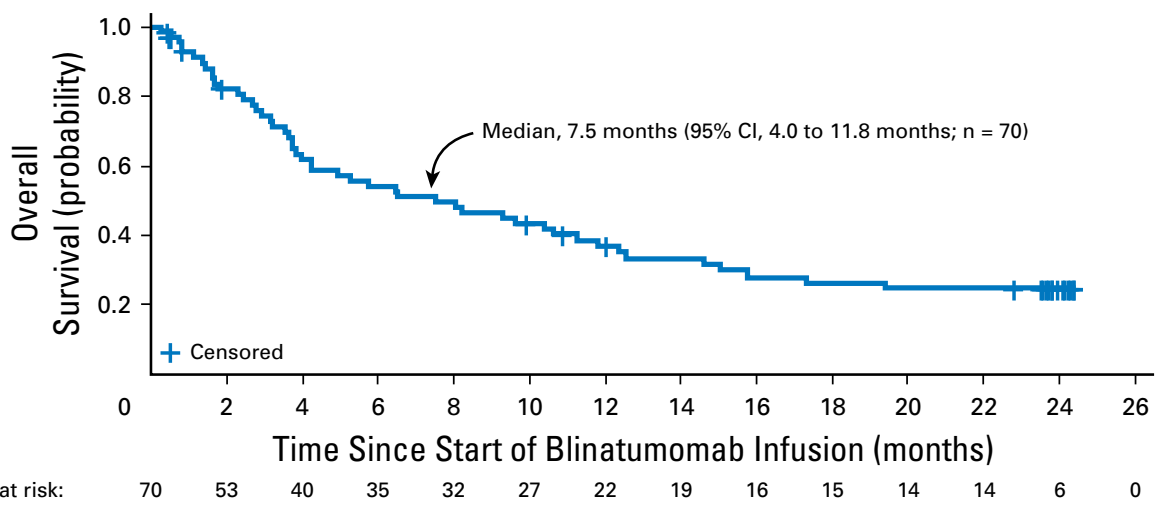

Fig 3. (A) Relapse-free survival in all 27 responders who received the recommended dosage. (B) Relapse-free survival among patients with complete remission according to minimal residual disease (MRD) response. (C) Overall survival in all patients who received the recommended dosage. Data are based on the 2-year follow-up. 


\begin{tabular}{|c|c|}
\hline Adverse Event & $\begin{array}{l}\text { All Patients } \\
(\mathrm{N}=70)^{*}\end{array}$ \\
\hline Patients with adverse events & $70(100)$ \\
\hline $\begin{array}{l}\text { Adverse events of worst grade } \geq 3 \text { occurring in } \geq 5 \% \text { of } \\
\text { patients }\end{array}$ & 61 (87) \\
\hline Anemia & $25(36)$ \\
\hline Thrombocytopenia & $15(21)$ \\
\hline Febrile neutropenia & $12(17)$ \\
\hline Hypokalemia & $12(17)$ \\
\hline Neutropenia & $12(17)$ \\
\hline Alanine aminotransferase increased & $11(16)$ \\
\hline Platelet count decreased & $10(14)$ \\
\hline Pyrexia & $10(14)$ \\
\hline Neutrophil count decreased & $9(13)$ \\
\hline Aspartate aminotransferase increased & $8(11)$ \\
\hline Leukopenia & $7(10)$ \\
\hline White blood cell count decreased & $7(10)$ \\
\hline Cytokine-release syndrome & $4(6)$ \\
\hline Hypertension & $4(6)$ \\
\hline Fatal adverse events on study $\dagger$ & $6(7)$ \\
\hline Multiorgan failureł & $2(3)$ \\
\hline Sepsis $\ddagger$ & $1(1)$ \\
\hline Fungal infection & $1(1)$ \\
\hline Respiratory failure $\ddagger$ & $1(1)$ \\
\hline Thrombocytopenia & $1(1)$ \\
\hline \multicolumn{2}{|c|}{$\begin{array}{l}\text { NOTE. Table shows adverse events regardless of relationship to treatment tha } \\
\text { occurred during the treatment period and until } 30 \text { days after the last treat } \\
\text { ment or before allogeneic hematopoietic stem-cell transplantation or start o } \\
\text { chemotherapy. } \\
{ }^{*} \text { All patients who received the recommended dose of } 5 / 15 \mu \mathrm{g} / \mathrm{m}^{2} / \mathrm{d} \text { in phase } \\
\text { or II. } \\
\text { †Does not include two deaths caused by disease progression, including one } \\
\text { patient who died as a result of recurrent leukemia. These deaths were reportec } \\
\text { by the investigators as adverse events. } \\
\text { fPatient died after allogeneic hematopoietic stem-cell transplantation afte } \\
\text { blinatumomab-induced remission (only one of the patients with multiorgar } \\
\text { failure). }\end{array}$} \\
\hline
\end{tabular}

Seventeen $(24 \%)$ of the 70 patients had neurologic/psychiatric events, mostly tremor $(\mathrm{n}=4,6 \%)$, dizziness $(\mathrm{n}=3,4 \%)$, and somnolence $(\mathrm{n}=3,4 \%)$, regardless of relation to treatment (Data Supplement). Three patients (4\%) experienced grade 3 neurologic events: somnolence (two patients) and neuralgia (one patient). Somnolence was a symptom of CRS in one patient and was associated with stroke in the other. There were no grade 4 or 5 neurologic events, but one patient had a grade 4 psychiatric event of confusion. The patient, who failed to respond to blinatumomab, stopped treatment after cycle 1 and developed disease progression. Seventeen days after treatment stop, the patient experienced sepsis with grade 4 confusion and intracranial hemorrhage. In nine patients (13\%), neurologic events, primarily tremor and dizziness, were considered to be treatment related. All of these events were of grade 2 and resolved. Two patients interrupted treatment because of grade 2 seizures. There were no permanent discontinuations caused by neurologic events.

Twenty-two of 70 patients treated with $5 / 15 \mu \mathrm{g} / \mathrm{m}^{2} / \mathrm{d}(31 \%)$ had elevated liver function parameters, including ALT $(\mathrm{n}=13$, $19 \%)$, AST ( $\mathrm{n}=10,14 \%)$, and blood bilirubin $(\mathrm{n}=4,6 \%)$. Elevations were seen during the first week of infusion and were transient, typically returning to baseline values within the first cycle. Increases in transaminases were observed without clinical symptoms/signs of hepatic toxicity (data not shown).

\section{DISCUSSION}

We established a stepwise blinatumomab dosage of $5 \mu \mathrm{g} / \mathrm{m}^{2} / \mathrm{d}$ for 1 week, followed by escalation to $15 \mu \mathrm{g} / \mathrm{m}^{2} / \mathrm{d}$ for the remaining infusion days, as the recommended dosage in children with relapsed/ refractory BCP-ALL, which is similar to the equivalent recommended dosage in adults. ${ }^{18,19}$ Among patients receiving 5/15 $\mu \mathrm{g} / \mathrm{m}^{2} / \mathrm{d}$, $39 \%$ achieved CR within the first two cycles, with most responders achieving complete MRD response. Blinatumomab showed antileukemic activity across all age groups, including patients $<2$ years old and those with unfavorable cytogenetics. Given the heavily pretreated population, we consider the CR rate to be clinically satisfactory, particularly in light of the observed toxicities. The few available reports on outcomes in comparable patient groups receiving conventional treatments have described dismal results. Most studies have reported low cytologic CR rates, with as few as $17 \%$ of patients with refractory first relapse achieving CR. ${ }^{6,7}$ Our data show CR rates of $30 \%$ in patients with refractory ALL and $48 \%$ in those with relapse not refractory to the last prior chemotherapy regimen. Furthermore, our cohort had particularly unfavorable characteristics: $>70 \%$ of patients had relapsed within 6 months of the previous treatment attempt.

Three of five DLTs in the dosage-finding phase were CRS, which was mitigated subsequently by administering a stepwise blinatumomab dosage. Neurologic events, frequently observed in adult patients receiving blinatumomab, ${ }^{13,18-20}$ were rare in our pediatric cohort. Most of the grade $\geq 3$ AEs were cytopenias and blood chemistry changes, attributable in part to the underlying leukemia and heavy pretreatment. After managing fever and hypotension during the critical first 3 days of the initial cycle, patients could be treated on an outpatient basis. All fatal AEs not considered DLTs occurred after blinatumomab infusion was stopped and other treatments, including alloHSCT or intensive chemotherapy, were administered; therefore, they were not considered related to blinatumomab.

In a recent large study of blinatumomab in adults with MRDpositive BCP-ALL, ${ }^{21}$ rates of CRS were low, suggesting that CRS was related to tumor burden. The results of our study, which required $>25 \%$ bone marrow blasts at baseline, support that hypothesis. In contrast, an earlier study in adults with MRDpositive disease reported higher incidences of neurologic events than those seen in our pediatric study. ${ }^{16,17}$ This finding may be related to a low CD19-positive target burden in blood or bone marrow, possibly revealing a higher probability of drug activity beyond the blood-brain barrier. ${ }^{18,20,22}$ Retrospective analyses in adult relapsed/refractory ALL showed that lower leukemia burden ( $<50 \%$ bone marrow blasts at baseline) was associated with better CR rates. ${ }^{19}$ We noted a similar trend in our population. These data suggest further investigation of blinatumomab, using a higher starting dosage of $15 \mu \mathrm{g} / \mathrm{m}^{2} / \mathrm{d}$, in children with BCP-ALL who have reduced leukemia load after induction therapy and thus a presumably lower risk of CRS. Such studies are underway (Clinical trial information: NCT02101853, NCT02393859).

Twenty-four patients (34\%) received alloHSCT as permitted per protocol, including seven who had had a prior transplantation. The data support the feasibility of using blinatumomab-induced T-cell activation in patients with prior alloHSCT, but require 
further investigation. Reports of compassionate use of blinatumomab in children with relapsed/refractory disease and prior alloHSCT have shown that blinatumomab did not induce or exacerbate graft-versus-host disease. ${ }^{23,24}$ B-cell deficiency after chronic, blinatumomab-induced depletion of CD19-positive cells can be managed with immunoglobulin infusions. ${ }^{25}$ In our study, analysis of long-term immunoglobulin levels in patients who responded to blinatumomab but did not proceed to alloHSCT, as reported for adults with $\mathrm{MRD}$-positive ALL, ${ }^{26}$ is ongoing.

Several studies have investigated or are investigating alternative treatments for ALL, including anti-CD22 epratuzumab ${ }^{27}$ and inotuzumab ozogamicin. ${ }^{28}$ Among CD19-directed approaches, chimeric antigen receptor (CAR) T-cell technology has shown high remission rates in pediatric relapsed/refractory BCPALL. Among 30 patients (mainly children) with relapsed/refractory ALL receiving anti-CD19 CAR T cells, 90\% achieved CR; however, $27 \%$ had severe CRS requiring intensive care up to mechanical ventilation, and $>40 \%$ had neurotoxicity. ${ }^{29,30}$ In both CD19targeted approaches, blinatumomab and CD19 CAR T cells, CD19negative relapses have been reported. ${ }^{19,29}$ Escape mechanisms likely vary and may include pre-existing CD19-negative clones, or CD19 mutations and/or expression of truncated CD19 from alternatively spliced isoforms, as reported recently for CART-19 epitopes. ${ }^{31}$ Future strategies may need to integrate therapies targeting different antigens to circumvent such escape mechanisms.

In summary, we identified the MTD and a recommended dosage for immunotherapy with single-agent blinatumomab in children and adolescents with BCP-ALL who were refractory or in second relapse or who had relapsed after alloHSCT. Blinatumomab showed antileukemic activity across age and risk groups. This study supports further evaluation of blinatumomab in children with BCP-ALL, including those with first-relapse or newly diagnosed disease at high risk of treatment failure because of significant MRD burden or unfavorable cytogenetics.

\section{AUTHORS' DISCLOSURES OF POTENTIAL CONFLICTS} OF INTEREST

Disclosures provided by the authors are available with this article at www.jco.org.

\section{AUTHOR CONTRIBUTIONS}

Conception and design: Arend von Stackelberg, Franco Locatelli, Gerhard Zugmaier, James A. Whitlock, Lia Gore

Provision of study materials or patients: Arend von Stackelberg, Tanya M. Trippett, Peter Bader, Deepa Bhojwani, Susan R. Rheingold, Christian M. Zwaan, Steven G. DuBois, Lia Gore

Collection and assembly of data: Arend von Stackelberg, Rupert Handgretinger, Tanya M. Trippett, Carmelo Rizzari, Peter Bader, Maureen M. O'Brien, Benoît Brethon, Deepa Bhojwani, Paul Gerhardt Schlegel, Arndt Borkhardt, Susan R. Rheingold, Todd Michael Cooper, Christian M. Zwaan, Phillip Barnette, Chiara Messina, Gérard Michel, Steven G. DuBois, Lia Gore

Data analysis and interpretation: Arend von Stackelberg, Gerhard Zugmaier, Rupert Handgretinger, Peter Bader, Deepa Bhojwani, Susan R. Rheingold, Christian M. Zwaan, Kuolung Hu, Min Zhu, James A. Whitlock, Lia Gore

Manuscript writing: All authors

Final approval of manuscript: All authors

Accountable for all aspects of the work: All authors

\section{REFERENCES}

1. World Health Organization: 4.1 Incidence of Childhood Leukaemia, an ENHIS Fact Sheet. Copenhagen, Denmark, World Health Organization, 2009. http://www.euro.who.int/en/health-topics/ noncommunicable-diseases/cancer/publications/ 2009/4.1-incidence-of-childhood-leukaemia,-an-enhisfact-sheet

2. Möricke $A$, Zimmermann $M$, Reiter $A$, et al: Long-term results of five consecutive trials in childhood acute lymphoblastic leukemia performed by the ALL-BFM study group from 1981 to 2000. Leukemia 24:265-284, 2010

3. Pui $\mathrm{CH}$, Robison $\mathrm{LL}$, Look $A T$ : Acute lymphoblastic leukaemia. Lancet 371:1030-1043, 2008

4. Parker $C$, Waters $R$, Leighton $C$, et al: Effect of mitoxantrone on outcome of children with first relapse of acute lymphoblastic leukaemia (ALL R3): An open-label randomised trial. Lancet 376:2009-2017, 2010

5. Tallen G, Ratei R, Mann G, et al: Long-term outcome in children with relapsed acute lymphoblastic leukemia after time-point and site-of-relapse stratification and intensified short-course multidrug chemotherapy: Results of trial ALL-REZ BFM 90. J Clin Oncol 28:2339-2347, 2010

6. Ko RH, Ji L, Barnette $P$, et al: Outcome of patients treated for relapsed or refractory acute Iymphoblastic leukemia: A Therapeutic Advances in Childhood Leukemia Consortium study. J Clin Oncol 28:648-654, 2010
7. von Stackelberg A, Völzke E, Kühl JS, et al: Outcome of children and adolescents with relapsed acute lymphoblastic leukaemia and non-response to salvage protocol therapy: A retrospective analysis of the ALL-REZ BFM Study Group. Eur J Cancer 47: 90-97, 2011

8. Tedder TF, Inaoki M, Sato S: The CD19-CD21 complex regulates signal transduction thresholds governing humoral immunity and autoimmunity. Immunity 6:107-118, 1997

9. Hasegawa M, Fujimoto M, Poe JC, et al: CD19 can regulate $B$ lymphocyte signal transduction independent of complement activation. J Immunol 167:3190-3200, 2001

10. von Stackelberg A: Monoclonal antibodies in paediatric acute lymphoblastic leukemia, in Saha V, Kearns $P$ (eds): New Agents for the Treatment of Acute Lymphoblastic Leukaemia. New York, NY, Springer Science and Business Media, 2011, pp 221 271

11. Dreier $T$, Lorenczewski $G$, Brandl $C$, et al: Extremely potent, rapid and costimulation-independent cytotoxic T-cell response against lymphoma cells catalyzed by a single-chain bispecific antibody. Int J Cancer 100:690-697, 2002

12. Hoffmann $P$, Hofmeister $R$, Brischwein $K$, et al: Serial killing of tumor cells by cytotoxic T cells redirected with a CD19-/CD3-bispecific singlechain antibody construct. Int J Cancer 115:98-104, 2005

13. Topp MS, Gökbuget N, Stein AS, et al: Safety and activity of blinatumomab for adult patients with relapsed or refractory B-precursor acute lymphoblastic leukaemia: A multicentre, single-arm, phase 2 study. Lancet Oncol 16:57-66, 2015

14. National Cancer Institute: Common Terminology Criteria for Adverse Events v4.03. Bethesda, MD, National Institutes of Health, 2010

15. Skolnik JM, Barrett JS, Jayaraman B, et al: Shortening the timeline of pediatric phase I trials: The rolling six design. J Clin Oncol 26:190-195, 2008

16. Simon R: Optimal two-stage designs for phase II clinical trials. Control Clin Trials 10:1-10, 1989

17. Teachey DT, Rheingold $S R$, Maude $S L$, et al: Cytokine release syndrome after blinatumomab treatment related to abnormal macrophage activation and ameliorated with cytokine-directed therapy. Blood 121 . 5154-5157, 2013

18. Topp MS, Gökbuget N, Zugmaier G, et al: Long-term follow-up of hematologic relapse-free survival in a phase 2 study of blinatumomab in patients with MRD in B-lineage ALL. Blood 120: 5185-5187, 2012

19. Topp MS, Gökbuget N, Zugmaier G, et al: Phase II trial of the anti-CD19 bispecific T cell-engager blinatumomab shows hematologic and molecular remissions in patients with relapsed or refractory B-precursor acute lymphoblastic leukemia. J Clin Oncol 32:4134-4140, 2014

20. Topp MS, Kufer P, Gökbuget N, et al: Targeted therapy with the T-cell-engaging antibody blinatumomab of chemotherapy-refractory minimal residual disease in B-lineage acute lymphoblastic leukemia patients results in high response rate and prolonged leukemia-free survival. J Clin Oncol 29:2493-2498, 2011 
21. Goekbuget $N$, Dombret $H$, Bonifacio $M$, et al: BLAST: A confirmatory, single-arm, phase 2 study of blinatumomab, a bispecific T-cell engager (BiTE®) antibody construct, in patients with minimal residual disease B-precursor acute lymphoblastic leukemia (ALL). Blood 124:379, 2014 (abstr)

22. Zugmaier $G$, Nagorsen $D$, Klinger $M$, et al: Identification of a predictive factor for reversible neurological adverse events in a subset of Non-Hodgkin lymphoma patients treated with CD19-specific BiTE ${ }^{\circledR}$ antibody blinatumomab. Blood 114:4793, 2009 (abstr)

23. Handgretinger R, Zugmaier G, Henze G, et al: Complete remission after blinatumomab-induced donor T-cell activation in three pediatric patients with post-transplant relapsed acute lymphoblastic leukemia. Leukemia 25:181-184, 2011

24. Schlegel $P$, Lang $P$, Zugmaier $G$, et al: Pediatric posttransplant relapsed/refractory B-precursor acute
Iymphoblastic leukemia shows durable remission by therapy with the T-cell engaging bispecific antibody blinatumomab. Haematologica 99:1212-1219, 2014

25. Uckun FM, Jaszcz W, Ambrus JL, et al: Detailed studies on expression and function of CD19 surface determinant by using B43 monoclonal antibody and the clinical potential of anti-CD19 immunotoxins. Blood 71:13-29, 1988

26. Zugmaier G, Topp MS, Alekar S, et al: Longterm follow-up of serum immunoglobulin levels in blinatumomab-treated patients with minimal residual disease-positive B-precursor acute lymphoblastic leukemia. Blood Cancer J 4:244, 2014

27. Raetz EA, Cairo MS, Borowitz MJ, et al: Reinduction chemoimmunotherapy with epratuzumab in relapsed acute lymphoblastic leukemia (ALL): Phase II results from Children's Oncology Group (COG) study ADVL04P2. Pediatr Blood Cancer 62:1171-1175, 2015
28. Kantarjian $H$, Thomas $D$, Jorgensen J, et al: Inotuzumab ozogamicin, an anti-CD22-calecheamicin conjugate, for refractory and relapsed acute lymphocytic leukaemia: A phase 2 study. Lancet Oncol 13:403-411, 2012

29. Grupp SA, Kalos M, Barrett D, et al: Chimeric antigen receptor-modified $T$ cells for acute lymphoid leukemia. N Engl J Med 368:1509-1518, 2013

30. Maude SL, Teachey DT, Porter DL, et al: CD19-targeted chimeric antigen receptor T-cell therapy for acute lymphoblastic leukemia. Blood 125: 4017-4023, 2015

31. Sotillo E, Barrett DM, Black KL, et al: Convergence of acquired mutations and alternative splicing of CD19 enables resistance to CART-19 immunotherapy. Cancer Discov 5:1282-1295, 2015

\section{Affiliations}

Arend von Stackelberg, Charité Campus Virchow, Berlin; Gerhard Zugmaier, Amgen Research (Munich), Munich; Rupert Handgretinger, University of Tübingen, Tübingen; Peter Bader, Hospital for Children and Adolescents III, University of Frankfurt, Frankfurt; Paul Gerhardt Schlegel, University Children's Hospital Würzburg, Würzburg; Arndt Borkhardt, University of Düsseldorf Medical Faculty, Düsseldorf, Germany; Franco Locatelli, Ospedale Pediatrico Bambino Gesù, Rome, University of Pavia, Pavia; Carmelo Rizzari, San Gerardo Hospital, University of Milano-Bicocca, Monza; Chiara Messina, Clinica di Oncoematologia Pediatrica, Università degli Studi di Padova, Padova, Italy; Benoît Brethon, Hôpital Robert Debré, Service Hématologie-Immunologie Pédiatrique, Paris; Gérard Michel, Hôpital de la Timone, Marseille, France; Christian M. Zwaan, Erasmus Medical Center, Sophia Children's Hospital, Rotterdam, Netherlands; Tanya M. Trippett, Memorial Sloan Kettering Cancer Center, New York, NY; Maureen M. O’Brien, Cincinnati Children's Hospital Medical Center, Cincinnati, OH; Deepa Bhojwani, Children's Hospital of Los Angeles; Kuolung Hu and Min Zhu, Amgen, Thousand Oaks, CA; Susan R. Rheingold, Children's Hospital of Philadelphia, Philadelphia, PA; Todd Michael Cooper, Seattle Children's Hospital, Seattle, WA; Phillip Barnette, Primary Children's Medical Center, Salt Lake City, UT; Steven G. DuBois, Dana-Farber/Boston Children's Cancer and Blood Disorders Center and Harvard Medical School, Boston, MA; Lia Gore, University of Colorado School of Medicine and Children's Hospital Colorado, Aurora, CO; and James A. Whitlock, University of Toronto, Hospital for Sick Children, Toronto, Ontario, Canada. 


\section{AUTHORS' DISCLOSURES OF POTENTIAL CONFLICTS OF INTEREST}

Phase I/Phase II Study of Blinatumomab in Pediatric Patients With Relapsed/Refractory Acute Lymphoblastic Leukemia

The following represents disclosure information provided by authors of this manuscript. All relationships are considered compensated. Relationships are self-held unless noted. I = Immediate Family Member, Inst = My Institution. Relationships may not relate to the subject matter of this manuscript. For more information about ASCO's conflict of interest policy, please refer to www.asco.org/rwc or jco.ascopubs.org/site/ifc.

Arend von Stackelberg

Honoraria: Amgen, ERYTECH Pharma, Novartis, Roche, Jazz

Pharmaceuticals

Consulting or Advisory Role: Amgen, ERYTECH Pharma, Novartis, Roche

Speakers' Bureau: Amgen

Travel, Accommodations, Expenses: Amgen, ERYTECH Pharma

Franco Locatelli

Honoraria: Amgen, Miltenyi Biotec

Consulting or Advisory Role: Amgen

Research Funding: Neovii Biotech

Travel, Accommodations, Expenses: Medac

Gerhard Zugmaier

Employment: Amgen Research (Munich) GmbH

Stock or Other Ownership: Amgen

Patents, Royalties, Other Intellectual Property: Amgen, Micromet

Rupert Handgretinger

Patents, Royalties, Other Intellectual Property: Miltenyi Biotec

Tanya M. Trippett

No relationship to disclose

Carmelo Rizzari

Honoraria: Jazz Pharmaceuticals

Consulting or Advisory Role: Jazz Pharmaceuticals

Peter Bader

Consulting or Advisory Role: Amgen (Inst), Novartis (Inst)

Research Funding: Medac (Inst), Neovii Biotech (Inst), RIEMSER (Inst)

Maureen M. O'Brien

Consulting or Advisory Role: Amgen

Research Funding: Amgen (Inst), Seattle Genetics (Inst), Epizyme (Inst), Celgene (Inst)

Travel, Accommodations, Expenses: Amgen, Celgene

Benoît Brethon

Travel, Accommodations, Expenses: Amgen

Deepa Bhojwani

Travel, Accommodations, Expenses: Amgen

Paul Gerhardt Schlegel

No relationship to disclose

Arndt Borkhardt

No relationship to disclose

Susan R. Rheingold

Employment: Axovant (I), Endo Pharmaceuticals (I)

Stock or Other Ownership: Axovant (I)

Todd Michael Cooper

Consulting or Advisory Role: Astellas Pharma, Celgene

Travel, Accommodations, Expenses: Celgene
Christian M. Zwaan

Consulting or Advisory Role: Pfizer (Inst), Daichii Sankyo (Inst), Celgene (Inst),

Travel, Accommodations, Expenses: Jazz Pharmaceuticals

Phillip Barnette

Stock or Other Ownership: Becton Dickinson, Celgene, Gilead Sciences, Edwards Lifesciences

Chiara Messina

No relationship to disclose

Gérard Michel

Consulting or Advisory Role: Amgen

Travel, Accommodations, Expenses: Amgen

Steven G. DuBois

Honoraria: Loxo

Consulting or Advisory Role: Loxo

Research Funding: Millennium Pharmaceuticals (Inst), Merck (Inst), Novartis (Inst)

Travel, Accommodations, Expenses: Loxo

Kuolung $\mathrm{Hu}$

Leadership: Amgen

Stock or Other Ownership: Amgen

Min Zhu

Employment: Amgen

Stock or Other Ownership: Amgen

James A. Whitlock

Honoraria: prIME Oncology, Medical Learning Group, Wave Healthcare, Jazz Pharmaceuticals

Consulting or Advisory Role: Spectrum Pharmaceuticals, Amgen, Eviti, Janssen-Ortho

Research Funding: GlaxoSmithKline, Novartis, Kite Pharma, Pfizer

Lia Gore

Employment: ARIAD Pharmaceuticals (I)

Leadership: ARIAD Pharmaceuticals(I)

Stock or Other Ownership: ARIAD Pharmaceuticals (I), Amgen, Sanofi, Celgene, Clovis Oncology, Agios (I)

Honoraria: Genentech/Roche, Jazz Pharmaceuticals, GlaxoSmithKline, Spectrum Pharmaceuticals, Amgen, Medscape

Consulting or Advisory Role: Meryx Pharmaceuticals, Celgene, GlaxoSmithKline, Amgen, ProEd Communications

Patents, Royalties, Other Intellectual Property: Patent held for diagnostic discovery and treatment response methodology tools in the use of MR spectroscopy for leukemia.

Travel, Accommodations, Expenses: Amgen, GlaxoSmithKline 


\section{Acknowledgment}

This study was formally approved by Innovative Therapies for Children with Cancer. We thank Beate D. Quednau (Amgen) for assistance in the preparation of this manuscript. We also thank Miranda Tradewell and Ali Hassan (Complete Healthcare Communications, Chadds Ford, PA), for the development of an initial draft of the methods and results and for assistance with formatting. Their work was funded by Amgen.

\section{Appendix}

\begin{tabular}{|c|c|c|c|c|c|}
\hline \multirow[b]{3}{*}{ 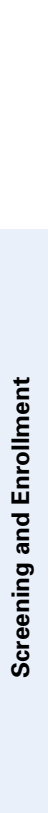 } & \multicolumn{3}{|c|}{$\begin{array}{l}\text { Phase I (rolling six design; } n=49 \text { ) } \\
\text { Intensive PK and toxicity evaluation } \\
\text { Determination of recommended dosage for phase II }\end{array}$} & \multicolumn{2}{|c|}{$\begin{array}{l}\text { Phase II (two-stage design; } n=44 \text { ) } \\
\text { Efficacy and toxicity evaluation at recommended dosage }\end{array}$} \\
\hline & $\begin{array}{c}\text { Dosage Escalation } \\
\qquad(n=23)^{*}\end{array}$ & & $\begin{array}{c}\text { PK Expansion } \\
(n=26)\end{array}$ & & \\
\hline & $\begin{array}{c}\begin{array}{c}\text { Cohort } 1 \\
5 \mu \mathrm{g} / \mathrm{m}^{2} / \mathrm{d} \\
(\mathrm{n}=5)\end{array} \\
\begin{array}{c}\text { Cohort } 2 \\
15 \mu \mathrm{g} / \mathrm{m}^{2} / \mathrm{d} \\
(\mathrm{n}=7)\end{array} \\
\mid \\
\text { Cohort } 3 \\
30 \mu \mathrm{g} / \mathrm{m}^{2} / \mathrm{d} \\
(\mathrm{n}=5) \\
\mid \\
\text { Cohort } 4 \\
15 / 30 \mu \mathrm{g} / \mathrm{m}^{2} / \mathrm{d} \\
(\mathrm{n}=6)\end{array}$ & 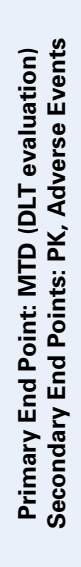 & $\begin{array}{c}\text { Recommended dosage } \\
\text { ( } \mathrm{n}=26) \\
5 / 15 \mu \mathrm{g} / \mathrm{m}^{2} / \mathbf{d} \\
\mathrm{cIV} \text { infusion } \\
4 \text { weeks on, } \\
2 \text { weeks off } \\
\text { Up to } 5 \text { cycles } \\
\text { Intensive PK } \\
\text { (n = 26) } \\
\text { Age groups: } \\
7 \text { to } 17 \text { years } \dagger \\
\text { (n = 9) } \\
2 \text { to } 6 \text { years } \dagger \\
\text { (n =9) } \\
<2 \text { years } \\
\text { (n = 8) }\end{array}$ & $\begin{array}{c}\text { Recommended dosage } \\
\text { ( } \mathrm{n}=44 \text { ) } \\
5 / 15 \mu \mathrm{g} / \mathrm{m}^{2} / \mathrm{d} \\
\mathrm{cIV} \text { infusion } \\
4 \text { weeks on, } \\
2 \text { weeks off } \\
\text { Up to } 5 \text { cycles } \\
\\
\\
\text { Age groups: } \\
7 \text { to } 17 \text { years } \\
\text { ( } \mathrm{n}=31 \text { ) } \\
2 \text { to } 6 \text { years } \\
\text { ( } \mathrm{n}=11 \text { ) } \\
<2 \text { years } \\
\text { ( } \mathrm{n}=2 \text { ) }\end{array}$ & $\begin{array}{l}\text { End points } \\
\text { Primary } \\
\text { Rate of CR within } \\
\text { the first two cycles } \\
\text { Secondary } \\
\text { Incidence, severity } \\
\text { of adverse events } \\
\text { Ability to proceed } \\
\text { to HSCT } \\
\text { OS } \\
\text { RFS } \\
\text { Time to relapse } \\
\text { Duration of CR } \\
\text { Exploratory } \\
\text { Rate of MRD } \\
\text { response }\end{array}$ \\
\hline
\end{tabular}

Fig A1. Study design. $\left(^{*}\right)$ Only patients 2 to 17 years old were enrolled. (†) Patients in the two older age groups were evaluated first before enrollment of patients

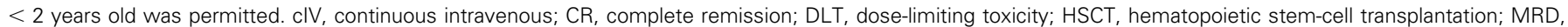
minimal residual disease; MTD, maximum tolerated dose; OS, overall survival; PK, pharmacokinetics; RFS, relapse-free survival. 